\title{
Distribution of Copper, Cadmium, and Lead in Soils from Former Industrialized Urban Areas of Beijing, China
}

\author{
Wei Luo $\cdot$ Yonglong Lu $\cdot$ Xiaojuan Tong \\ Bin Wang · Guang Wang · Yajuan Shi · Tieyu Wang • \\ Jonathan Naile $\cdot$ John P. Giesy
}

Received: 24 May 2008/Accepted: 3 December 2008/Published online: 13 December 2008

(C) Springer Science+Business Media, LLC 2008

\begin{abstract}
Concentrations and distributions of cadmium, copper, and lead in soils from several industrialized urban areas of Beijing, China were investigated. The mean concentration of $\mathrm{Cd}$ in surface soils was not significantly greater than the regional background concentration, while those of $\mathrm{Cu}$ and $\mathrm{Pb}$ were significantly greater than regional background concentrations. All soil profiles exhibited a decreasing trend in concentrations of $\mathrm{Cd}, \mathrm{Cu}$, and $\mathrm{Pb}$ with depth. Concentrations of $\mathrm{Cu}$ and $\mathrm{Pb}$ were greatest at a depth of $0-80 \mathrm{~cm}$, and exceeded the regional concentrations. Concentrations of $\mathrm{Cd}, \mathrm{Cu}$, and $\mathrm{Pb}$ at some industrial sites would necessitate active remedial actions.
\end{abstract}

W. Luo · Y. Lu (ه) - B. Wang · G. Wang · Y. Shi · T. Wang State Key Lab of Urban and Regional Ecology, Research Center for Eco-Environmental Sciences, Chinese Academy of Sciences, Beijing 100085, China

e-mail: yllu@rcees.ac.cn

W. Luo

e-mail: luow@rcees.ac.cn

X. Tong

College of Forestry, Beijing Forestry University,

Beijing 100083, China

J. Naile · J. P. Giesy

Department of Veterinary Biomedical Sciences and Toxicology

Centre, University of Saskatchewan, Saskatoon, SK, Canada

J. P. Giesy

Zoology Department, National Food Safety and Toxicology

Center and Center for Integrative Toxicology, Michigan State

University, East Lansing, MI 48824, USA

\section{J. P. Giesy}

Centre for Coastal Pollution and Conservation,

Department of Biology and Chemistry, City University of Hong

Kong, Tat Chee Avenue, Kowloon, Hong Kong SAR, China
Keywords Heavy metals - Soil contamination · Industrialized urban areas

Due to increased demand for housing in China, industrial complexes are being moved from urban areas to the suburbs and the former industrial districts are being developed as housing. The people living in communities built on former industrial sites may be at risk of cancer and other adverse health effects, even long after the source is removed (Stephens et al. 2004). Thus, contamination of former industrial sites is a critical and pressing environmental issue in China. Some studies have been undertaken on metal contamination of soils as a result of industrial activities, especially those that took place in cities (Weiss et al. 1994; Nriagu and Pacyna 1988). Soils at former industrial sites are particularly prone to having relatively great concentrations of $\mathrm{Cu}, \mathrm{Cd}$, and $\mathrm{Pb}$ that are derived from the discharge of a variety of industrial pollutants in the form of gases, liquids, and solids to land (Fakoyade and Onianwa 2002). Excessive $\mathrm{Pb}, \mathrm{Cd}$, and $\mathrm{Cu}$ exposure can cause severe health effects in humans (Flora 2002; Nordberg 2003; Yaman and Akdeniz 2004).

The industrialization of Beijing began in the 1950s. The number of industrial plants reached approximately 20,000 by the end of the 1990s. With Beijing's successful bid to host the Olympic Games in 2008 and the rapid expansion of urban areas in recent years, most industrial plants in the city are being shut down or removed from downtown to sub-cities and the former industrial sites have been converted into commercial and residential properties. However, there have been relatively few such studies conducted in these industrial areas inside Beijing City. For the first time, we have investigated total copper, cadmium 
and lead concentrations in soils, interpreted the profiles of their concentration versus depth, and discussed their contaminations in former industrial sites of Beijing, China. The results obtained in our studies can be used by authorities to identify former sources of pollution, locate polluted areas for remediation and to choose the proper remediation strategy.

\section{Materials and Methods}

Five representative industrial sites (denoted A, B, C, D and E) in the industrialized area located approximately $1-8 \mathrm{~km}$ southeast of downtown Beijing, China were studied. The description of the five former industrial plants corresponding to the sites is presented (Table 1). Sampling points were selected depending on the location of production and waste treatment sectors, which took up most of the site and were potentially important sources of contamination. Fifty-eight surface soil sample points and 27 profile pits were selected (Fig. 1). Four sub-samples of the topsoil $(0-10 \mathrm{~cm})$ were collected at each sampling point and mixed thoroughly to get a representative surface soil sample. The deep layer soil samples were taken from each profile pit at depths of 20,80,180, and $400 \mathrm{~cm}$. Therefore, a total of 58 representative surface soil samples and 108 deep layer soil samples were obtained. Prior to analysis, stones and foreign objects were removed by hand, and the soil samples were air-dried at room temperature for 7 day, gently crushed in an agate mortar, completely passed through a nylon sieve of 100 meshes $(0.149 \mathrm{~mm})$, and then stored in glass bottles. Aliquants of approximately $0.250 \mathrm{~g}$ sample were accurately weighed in a $250 \mathrm{~mL}$ Pyrex Erlenmeyer flask and $10 \mathrm{~mL}$ of $8.5 \mathrm{M} \mathrm{HNO}_{3}$ were added. The solution was heated on a hot plate to $\sim 95^{\circ} \mathrm{C}$ without boiling and this temperature was maintained for $15 \mathrm{~min}$. After cooling to less than $70^{\circ} \mathrm{C}, 5 \mathrm{~mL}$ of $17 \mathrm{M} \mathrm{HNO}_{3}$ were added and the sample was refluxed for $30 \mathrm{~min}$ at $\sim 95^{\circ} \mathrm{C}$ without boiling. This step was repeated a second time. The sample was evaporated to $\sim 5 \mathrm{~mL}$ without boiling. After cooling to less than $70^{\circ} \mathrm{C}, 2 \mathrm{~mL}$ of water were added followed by the slow addition of $3 \mathrm{~mL}$ of $8.8 \mathrm{M} \mathrm{H}_{2} \mathrm{O}_{2}$. The solution was then heated until effervescence subsided. After cooling to less than $70^{\circ} \mathrm{C} 10 \mathrm{~mL}$ of $12 \mathrm{M} \mathrm{HCl}$ were added and the sample was refluxed for $15 \mathrm{~min}$. without boiling. After cooling to room temperature, the sample was filtered and diluted to $25 \mathrm{~mL}$ with water. The full description of the method is reported in the related USEPA standard 3050B (1996). Total concentrations of $\mathrm{Cu}, \mathrm{Cd}$, and $\mathrm{Pb}$ in the digests were analyzed using inductively coupled plasma-mass spectrometry (ICP-MS) (7500a Agilent Technologies). Standard reference materials, GBW07427 soils, obtained from Center of National Standard Reference Material of China, were inserted for quality assurance and quality control $(\mathrm{QA} / \mathrm{QC})$ procedures. Average recoveries of $\mathrm{Cu}, \mathrm{Cd}$, and $\mathrm{Pb}$ in triplicate analysis were $96 \pm 2.1 \%, 99 \pm 1.4 \%, 104 \pm 5.0 \%$, respectively. The detection limits were $0.04 \mathrm{mg} / \mathrm{kg}$ for $\mathrm{Cu}, 0.01 \mathrm{mg} / \mathrm{kg}$ for $\mathrm{Cd}$ and $0.01 \mathrm{mg} / \mathrm{kg}$ for $\mathrm{Pb}$.

Statistical analyses were conducted by use of Microsoft Excel and SPSS 10.01 (SPSS Inc., USA). The distributions of concentrations were tested to determine if they approximated the normal probability function with the Kolmogorov-Smirnov method. Concentrations of $\mathrm{Cu}, \mathrm{Cd}$, and $\mathrm{Pb}$ from each site were analyzed by use of a one way Analysis of Variance (ANOVA) to determine if they were different from one another. Differences between means were tested by Turkey's means comparison test for Post Hoc Multiple Comparisons. A significance level of $p<0.05$ was used throughout the study.

\section{Results and Discussion}

Summary statistics for $\mathrm{Cu}, \mathrm{Cd}$, and $\mathrm{Pb}$ in the surface soil samples at five industrial sites are presented (Table 2). Concentrations of $\mathrm{Cd}$ in surface soils from Site A ranged from 0.14 to $9.2 \mathrm{mg} / \mathrm{kg}$, dw with a mean concentration of $1.9 \mathrm{mg} / \mathrm{kg}, \mathrm{dw}$, which was significantly greater than any other Site $(p<0.05)$. The standard deviation $(3.6 \mathrm{mg} / \mathrm{kg}$, $\mathrm{dw}$ ) of Cd concentrations in soils of Site A was the greatest of all the Sites. This result suggests strong variability due to

Table 1 Descriptions of five industrial plants in urban areas of Beijing, China

\begin{tabular}{llllll}
\hline Plant & $\begin{array}{l}\text { Area } \\
\left(10^{6} \mathrm{~m}^{2}\right)\end{array}$ & $\begin{array}{l}\text { Year of } \\
\text { establishment }\end{array}$ & Produced products & $\begin{array}{l}\text { Environmental } \\
\text { accident events }\end{array}$ & $\begin{array}{l}\text { Proposed } \\
\text { land use }\end{array}$ \\
\hline A & 64.94 & 1958 & Chemical agents, fluorescent and photosensitive materials & 19 & Residential area \\
B & 7.95 & 1956 & $\begin{array}{l}\text { Pesticides, PVC plastic and rubber products } \\
\text { Coke, coal gas, ammonium-sulfate, benzene, } \\
\text { naphthalene and hydroxybenzene }\end{array}$ & 3 & 6 \\
C & 135 & 1959 & Pesticides, Lacquer, architectural and industrial pigments & 2 & Real estate \\
D & 18.5 & 1954 & Dyestuffs and painting products and vitriol & 0 & Real estate \\
E & 40 & 1956 & & & Real estate \\
\hline
\end{tabular}




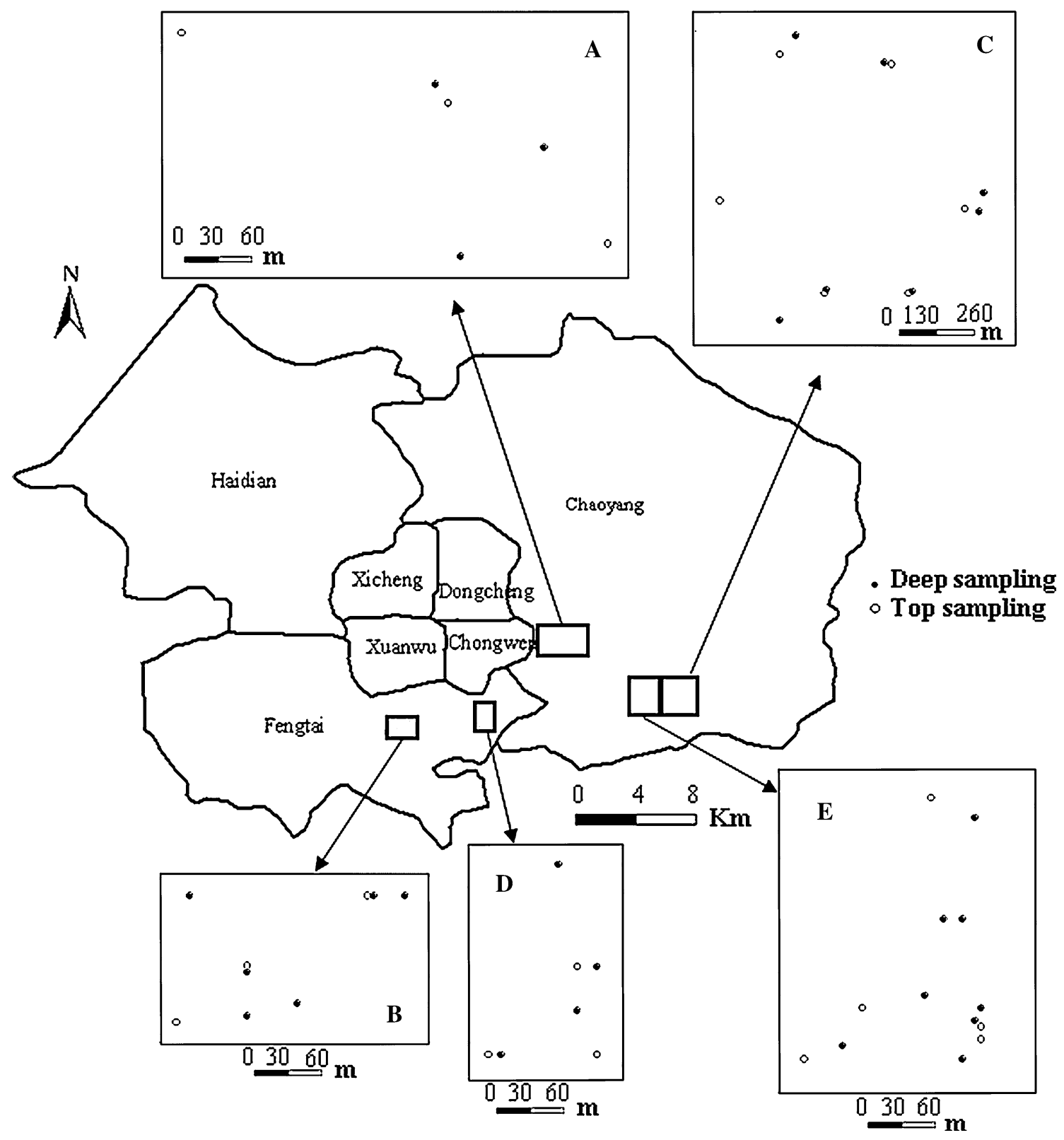

Fig. 1 Sampling scheme at the industrialized urban area of Beijing, China

the presence of different anthropogenic sources of $\mathrm{Cd}$ at Site A. The relatively great concentrations of $\mathrm{Cd}$ in soils of Site A might be attributed to metal-containing agents (including those containing cadmium) that were produced in the 1960s with relatively primitive and inefficient production techniques without any environmental treatment. However, significant differences in $\mathrm{Cd}$ concentrations among the other Sites (namely B, C, D, and E) were not observed, because the other Plants (with the exception of Plant A) did not produce any cadmium-containing products. This may explain the relatively lesser concentrations of $\mathrm{Cd}$ at the other Sites. Generally, the mean concentration of $\mathrm{Cd}$ in surface soils at industrial sites $(0.40 \mathrm{mg} / \mathrm{kg}, \mathrm{dw})$ was not significantly greater (one-sample T-test; $p>0.05$ ) than the mean concentration of $\mathrm{Cd}$ in less industrialized reference areas that represented the general background concentration of soils in the region $(0.15 \mathrm{mg} / \mathrm{kg}, \mathrm{dw})$. Hence, the surface soils from the Beijing industrial sites were not significantly contaminated by cadmium. Soils at Site E had a greater mean concentration of $\mathrm{Cu}(92 \pm 78 \mathrm{mg} / \mathrm{kg}, \mathrm{dw})$ than those from Sites B, C, and D $(p<0.05)$ (Table 2). Concentrations of $\mathrm{Cu}$ in the soils from Site $\mathrm{E}$ varied greatly based on range $\left(14-2.2 \times 10^{2} \mathrm{mg} / \mathrm{kg}, \mathrm{dw}\right)$ and standard deviation $(78 \mathrm{mg} /$ $\mathrm{kg}, \mathrm{dw}$ ). This could be attributed to the fact that Site E produced dyestuffs, painting products and vitriol, which required a substantial amount of $\mathrm{Cu}$-contained materials 
Table 2 Descriptive basic statistics of concentrations of $\mathrm{Cd}, \mathrm{Cu}$, and $\mathrm{Pb}(\mathrm{mg} / \mathrm{kg}, \mathrm{dw})$ in the surface soils at different industrial sites
* For the indicated elements, those values not showing a common small letters $(a, b)$ are significantly different at the level $(p<0.05)$

${ }^{a}$ Chen et al. (2004)

\begin{tabular}{llllll}
\hline Site & Mean* & Median & SD & Min & Mx \\
\hline Cadmium & & & & & \\
A $(\mathrm{n}=6)$ & $1.9 \mathrm{~b}$ & 0.46 & 3.6 & 0.14 & 9.2 \\
B $(\mathrm{n}=14)$ & $0.24 \mathrm{a}$ & 0.21 & 0.13 & 0.10 & 0.58 \\
C $(\mathrm{n}=14)$ & $0.22 \mathrm{a}$ & 0.16 & 0.20 & 0.09 & 0.88 \\
D $(\mathrm{n}=10)$ & $0.27 \mathrm{a}$ & 0.24 & 0.13 & 0.13 & 0.54 \\
E $(\mathrm{n}=14)$ & $0.18 \mathrm{a}$ & 0.14 & 0.10 & 0.08 & 0.43 \\
Overall (n=58) & 0.40 & 0.18 & 1.2 & 0.08 & 9.2 \\
Non-polluted soils $(\mathrm{n}=117)^{\mathrm{a}}$ & 0.15 & 0.11 & 0.11 & 0.03 & 0.63 \\
Copper & & & & & \\
A $(\mathrm{n}=6)$ & $40 \mathrm{ab}$ & 34 & 16 & 24 & 61 \\
B $(\mathrm{n}=14)$ & $29 \mathrm{a}$ & 26 & 15 & 14 & 70 \\
C $(\mathrm{n}=14)$ & $32 \mathrm{a}$ & 23 & 18 & 14 & 69 \\
D $(\mathrm{n}=10)$ & $37 \mathrm{a}$ & 33 & 16 & 21 & 75 \\
E $(\mathrm{n}=14)$ & $92 \mathrm{~b}$ & 55 & 78 & 14 & $2.2 \times 10^{2}$ \\
Overall (n=58) & 48 & 33 & 47 & 14 & $2.2 \times 10^{2}$ \\
Non-polluted soils $(\mathrm{n}=117)^{\mathrm{a}}$ & 20 & 19 & 6.3 & 6.0 & 38 \\
Lead & & & & & \\
A $(\mathrm{n}=6)$ & $52 \mathrm{a}$ & 48 & 25 & 22 & 92 \\
B $(\mathrm{n}=14)$ & $1.1 \times 10^{2} \mathrm{a}$ & 52 & $1.9 \times 10^{2}$ & 37 & $7.7 \times 10^{2}$ \\
C $(\mathrm{n}=14)$ & $83 \mathrm{a}$ & 56 & 73 & 22 & $3.0 \times 10^{2}$ \\
D $(\mathrm{n}=10)$ & $1.1 \times 10^{2} \mathrm{a}$ & 99 & 61 & 34 & $2.4 \times 10^{2}$ \\
E $(\mathrm{n}=14)$ & $46 \mathrm{a}$ & 44 & 24 & 17 & $1.1 \times 10^{2}$ \\
Overall (n=58) & 82 & 54 & $1.1 \times 10^{2}$ & 17 & $7.7 \times 10^{2}$ \\
Non-polluted soils $(\mathrm{n}=101)^{\mathrm{a}}$ & 25 & 25 & 5.1 & 12 & 38 \\
\hline & & & & & \\
\hline & & & & & \\
\end{tabular}

such as $\mathrm{C}_{22} \mathrm{H}_{16} \mathrm{~N}_{8} \mathrm{Cu}, \mathrm{C}_{32} \mathrm{H}_{2} \mathrm{Cl}_{14} \mathrm{Cu}$, and $\mathrm{CuCl}$. There was no significant difference in the concentrations of $\mathrm{Cu}$ among Sites B, C, and D $(p>0.05)$. The mean concentration of $\mathrm{Cu}$ in surface soils from all of the industrial sites $(48 \mathrm{mg} / \mathrm{kg}$, $\mathrm{dw})$ was significantly greater than that for the reference soils $(20 \mathrm{mg} / \mathrm{kg}, \mathrm{dw})$. Therefore, the industrial soils at these sites contained elevated levels of $\mathrm{Cu}$. Relatively greater mean concentrations of $\mathrm{Pb}\left(1.1 \times 10^{2} \pm 1.9 \times 10^{2} \mathrm{mg} / \mathrm{kg}\right.$, $\mathrm{dw}$ and $\left.1.1 \times 10^{2} \pm 61 \mathrm{mg} / \mathrm{kg}, \mathrm{dw}\right)$ were observed in surface soils from Sites B and D, although there was no statistically significant difference in the concentration of $\mathrm{Pb}$ between industrial sites. Pesticides, PVC plastic and rubber products were produced at Site $\mathrm{B}$. In addition $\mathrm{Pb}$-containing powder was used for production of industrial and architectural pigments at Site D, which might have caused greater concentrations of $\mathrm{Pb}$ in soils at Sites $\mathrm{B}$ and $\mathrm{D}$. The mean $\mathrm{Pb}$ concentration in all the industrial soil samples was significantly greater than that of soils in the reference locations. Thus, we concluded that the surface soils collected from Beijing industrial sites were contaminated by $\mathrm{Pb}$.

Concentrations of Cd (Mean \pm SD) at different depths of soil profiles taken from industrial sites are presented (Table 3). Mean concentrations of $\mathrm{Cd}$ in soil profiles tended to decrease with increasing depth. Cd concentrations at depths of $20-80 \mathrm{~cm}$ in soils from Site A were significantly greater than those at depths of greater than $80 \mathrm{~cm}$. This result indicated severe heavy metal pollution at the layers of $20-80 \mathrm{~cm}$. However, the $\mathrm{Cd}$ concentrations in soils deeper than $80 \mathrm{~cm}$ from Site A tended to be consistent with
Table $3 \mathrm{Cd}$ concentrations $(\mathrm{mg} / \mathrm{kg}, \mathrm{dw})$ in the soil profiles taken from different industrial sites

\begin{tabular}{lllll}
\hline Site & $20 \mathrm{~cm}$ & $80 \mathrm{~cm}$ & $180 \mathrm{~cm}$ & $400 \mathrm{~cm}$ \\
\hline A $(\mathrm{n}=3)$ & $3.4 \pm 5.1$ & $1.0 \pm 1.4$ & $0.13 \pm 0.080$ & $0.15 \pm 0.070$ \\
$\mathrm{~B}(\mathrm{n}=5)$ & $0.16 \pm 0.080$ & $0.11 \pm 0.020$ & $0.10 \pm 0.030$ & $0.12 \pm 0.020$ \\
C $(\mathrm{n}=7)$ & $0.23 \pm 0.29$ & $0.17 \pm 0.17$ & $0.17 \pm 0.20$ & $0.10 \pm 0.020$ \\
$\mathrm{D}(\mathrm{n}=4)$ & $0.21 \pm 0.060$ & $0.15 \pm 0.090$ & $0.10 \pm 0.040$ & $0.10 \pm 0.020$ \\
E $(\mathrm{n}=8)$ & $0.15 \pm 0.080$ & $0.17 \pm 0.19$ & $0.12 \pm 0.050$ & $0.11 \pm 0.030$ \\
Overall $(\mathrm{n}=27)$ & $0.54 \pm 1.75$ & $0.25 \pm 0.50$ & $0.12 \pm 0.10$ & $0.11 \pm 0.030$ \\
\hline
\end{tabular}


the mean concentration in non-polluted soils $(0.15 \mathrm{mg} / \mathrm{kg}$, $\mathrm{dw})$. This suggests that Cd pollution is not an issue below $80 \mathrm{~cm}$ and that leaching from less deep soils to deeper soils has been minimal. There was no statistically significant difference in concentrations of $\mathrm{Cd}$ among the depths of soil profiles at the other industrial sites, suggesting there was no significant Cd pollution in the deep layers of the other sites. Concentrations of $\mathrm{Cu}$ in the soil profiles decreased with increasing depth (Table 4). Mean concentrations of $\mathrm{Cu}$ at depths of 20 and $80 \mathrm{~cm}$ at Sites A, B and C were significantly greater than not only those at the depths of 180 and $400 \mathrm{~cm}$, but also the mean concentration in reference $(20 \mathrm{mg} / \mathrm{kg}, \mathrm{dw})$. These results demonstrate that significant amount of $\mathrm{Cu}$ at Sites $\mathrm{A}, \mathrm{B}$, and $\mathrm{C}$ leached to at least $80 \mathrm{~cm}$, although there was no significant contamination at the depth of $180 \mathrm{~cm}$. Copper in soils from Sites D and E has penetrated to at least $180 \mathrm{~cm}$ because its concentrations in soils at the depths of $180 \mathrm{~cm}$ were significantly greater than the concentration of $\mathrm{Cu}$ in reference soils $(20 \mathrm{mg} / \mathrm{kg}$, $\mathrm{dw})$. Thus, the soils at depths of $0-180 \mathrm{~cm}$ at Sites D and E were also contaminated by $\mathrm{Cu}$. Mean concentrations of $\mathrm{Cu}$ at the depths of $20-80 \mathrm{~cm}$ in the soil profiles were significantly greater than not only those at the depths of 180 and $400 \mathrm{~cm}$, but also reference soil. It could be concluded that the soils at the depths of $0-80 \mathrm{~cm}$ at Beijing industrial sites were contaminated by Copper. Concentrations of $\mathrm{Pb}$ in industrial soils from all sites decreased with increasing depth of the profiles (Table 5). Mean concentrations of $\mathrm{Pb}$

Table $4 \mathrm{Cu}$ concentrations $(\mathrm{mg} / \mathrm{kg}, \mathrm{dw})$ in the soil profiles taken from different industrial sites

\begin{tabular}{lllll}
\hline Site & $20 \mathrm{~cm}$ & $80 \mathrm{~cm}$ & $180 \mathrm{~cm}$ & $400 \mathrm{~cm}$ \\
\hline A $(\mathrm{n}=3)$ & $38 \pm 20$ & $22 \pm 7.8$ & $13 \pm 6.6$ & $9.4 \pm 7.0$ \\
B $(\mathrm{n}=5)$ & $32 \pm 20$ & $24 \pm 10$ & $14 \pm 8.8$ & $17 \pm 7.4$ \\
C $(\mathrm{n}=7)$ & $26 \pm 20$ & $22 \pm 6.6$ & $13 \pm 8.3$ & $14 \pm 4.0$ \\
$\mathrm{D}(\mathrm{n}=4)$ & $40 \pm 8.1$ & $37 \pm 13$ & $30 \pm 23$ & $16 \pm 3.3$ \\
E $(\mathrm{n}=8)$ & $85 \pm 80$ & $45 \pm 31$ & $37 \pm 27$ & $17 \pm 6.7$ \\
Overall $(\mathrm{n}=27)$ & $47 \pm 51$ & $30 \pm 20$ & $23 \pm 18$ & $15 \pm 5.7$ \\
\hline
\end{tabular}

Table $5 \mathrm{~Pb}$ concentrations $(\mathrm{mg} / \mathrm{kg}, \mathrm{dw})$ in the soil profiles taken from different industrial sites

\begin{tabular}{lllll}
\hline Site & $20 \mathrm{~cm}$ & $80 \mathrm{~cm}$ & $180 \mathrm{~cm}$ & $400 \mathrm{~cm}$ \\
\hline A $(\mathrm{n}=3)$ & $47 \pm 15$ & $26 \pm 17$ & $19 \pm 5.6$ & $3.4 \pm 1.8$ \\
$\mathrm{~B}(\mathrm{n}=5)$ & $78 \pm 47$ & $84 \pm 67$ & $30 \pm 21$ & $28 \pm 22$ \\
$\mathrm{C}(\mathrm{n}=7)$ & $67 \pm 48$ & $59 \pm 68$ & $27 \pm 24$ & $19 \pm 5.8$ \\
$\mathrm{D}(\mathrm{n}=4)$ & $1.0 \times 10^{2} \pm 41$ & $99 \pm 99$ & $68 \pm 77$ & $26 \pm 17$ \\
$\mathrm{E}(\mathrm{n}=8)$ & $42 \pm 16$ & $41 \pm 20$ & $34 \pm 19$ & $17 \pm 4.0$ \\
Overall $(\mathrm{n}=27)$ & $66 \pm 40$ & $59 \pm 57$ & $34 \pm 32$ & $19 \pm 12$ \\
\hline
\end{tabular}

at depths of 20,80 , and $180 \mathrm{~cm}$ at Site D were significantly $(p<0.05)$ greater than those at $400 \mathrm{~cm}(26 \mathrm{mg} / \mathrm{kg})$, similar to the concentration in reference soils $(25 \mathrm{mg} / \mathrm{kg})$. Mean concentrations of $\mathrm{Pb}$ at 20 and $80 \mathrm{~cm}$ at Sites $\mathrm{B}$ and $\mathrm{C}$ were significantly greater than those at the depths of 180 and $400 \mathrm{~cm}$. However, concentrations of $\mathrm{Pb}$ among the depths of the profiles at the Site E were not statistically significant. Generally, concentrations of $\mathrm{Pb}$ at depths of $20-80 \mathrm{~cm}$ at the industrial sites were significantly greater than not only those at depths of 180 and $400 \mathrm{~cm}$, but also those of regional reference soils $(25 \mathrm{mg} / \mathrm{kg}$, dw). Hence, it can be concluded that soils at $0-80 \mathrm{~cm}$ for the industrial sites have been contaminated by $\mathrm{Pb}$. Furthermore, mean concentrations of $\mathrm{Pb}$ at a depth of $400 \mathrm{~cm}$ in soil profiles at Sites $\mathrm{B}$ and $\mathrm{D}$ were greater than the regional reference soils. Therefore, $\mathrm{Pb}$ has leached at least $400 \mathrm{~cm}$ downward at these industrial sites.

Most countries have promulgated legislation on soil protection. Soil clean-up standards (SCSs) are often used as trigger criteria to determine the need for an in-depth soil investigation or for remediation. The needs for further soil investigation or remedial action are related to the exceedance of an SCS. However, there is no soil clean-up standard for different land uses for China to date. In this study, we used SCSs for $\mathrm{Cd}, \mathrm{Cu}$, and $\mathrm{Pb}$ for residential land use for some other countries to determine if there is a need to conduct an in-depth soil investigation, or to perform remedial action (Table 6). Mean concentrations of $\mathrm{Cd}$ in

Table 6 Soil clean-up standards for residential landuse for some countries (Provoost et al. 2006)

\begin{tabular}{llll}
\hline Country & $\begin{array}{l}\text { Cadmium } \\
(\mathrm{mg} / \mathrm{kg}, \mathrm{dw})\end{array}$ & $\begin{array}{l}\text { Copper } \\
(\mathrm{mg} / \mathrm{kg}, \mathrm{dw})\end{array}$ & $\begin{array}{l}\text { Lead } \\
(\mathrm{mg} / \mathrm{kg}, \mathrm{dw})\end{array}$ \\
\hline Belgium $^{\mathrm{a}}$ & 6.0 & $4.0 \times 10^{2}$ & $7.0 \times 10^{2}$ \\
Netherlands $^{\mathrm{b}}$ & 12 & $1.9 \times 10^{2}$ & $5.3 \times 10^{2}$ \\
Germany $^{\mathrm{b}}$ & 20 & $\mathrm{NA}$ & $4.0 \times 10^{2}$ \\
France & 20 & $1.9 \times 10^{2}$ & $0 \times 10^{2}$ \\
Sweden & 0.40 & $1.0 \times 10^{2}$ & 80 \\
Norway & 3.0 & $1.0 \times 10^{2}$ & 60 \\
Canada & 10 & 63 & $1.4 \times 10^{2}$ \\
Switzerland & 20 & $1.0 \times 10^{3} \mathrm{c}$ & $1.0 \times 10^{3} \mathrm{~d}$ \\
USA & 37 & $3.1 \times 10^{3}$ & $4.0 \times 10^{2}$ \\
\hline
\end{tabular}

NA not applicable

a Soil degree named Vlarebo from July 8, 2002

b Standards applicable as national legislation for 'wirkungspad Boden-Mensch' (exposure path soil-humans)

c 1000/4 related to the soil clean-up standard as total concentration and soluble concentration. The clean-up standard of $1,000 \mathrm{mg} / \mathrm{kg} \mathrm{dm}$ was used in this comparison

d $1000 / 0.1$ related to the soil clean-up standard as total concentration and soluble concentration. The clean-up standard of $1,000 \mathrm{mg} / \mathrm{kg} \mathrm{dm}$ was used in this comparison 
the soils at all Sites, with the exception of Site A were substantially less than the SCSs for most countries. However, the maximum values of $\mathrm{Cd}$ in surface soils samples from all the Sites (Table 2) did exceed the SCSs for Sweden $(0.40 \mathrm{mg} / \mathrm{kg})$. However, these concentrations were less than $0.40 \mathrm{mg} / \mathrm{kg}, \mathrm{dw}$ at greater depths of soil (Table 3). Site A had mean concentrations of $\mathrm{Cd}$ at depths of 0-80 $\mathrm{cm}$ greater than the SCS of Sweden $(0.40 \mathrm{mg} / \mathrm{kg})$, and some were even greater than the SCSs of Norway and Belgium, which are 3.0 and $6.0 \mathrm{mg} / \mathrm{kg}$, dw, respectively. So, remedial action or at least proper management for $\mathrm{Cd}$ contamination in the soils at the depths of $0-80 \mathrm{~cm}$ at Site A is necessary. Based on the SCSs of Canada $(63 \mathrm{mg} / \mathrm{kg})$, the soils at depths of $0-20 \mathrm{~cm}$ at Site E should be remediated. Alternatively, no remediation would be needed at the other industrial sites because the mean concentrations of $\mathrm{Cu}$ in the soils were less than the SCSs for all the countries (Table 6). Concentrations of lead in soils at $20 \mathrm{~cm}$ for Sites A and C, $0-80 \mathrm{~cm}$ for Site B, and $0-180 \mathrm{~cm}$ for Site D exceed the SCS of lead for Norway $(60 \mathrm{mg} / \mathrm{kg})$. Only concentrations of $\mathrm{Pb}$ in the soils at depths of 0-10 cm for Sites A, C, and D, 0-80 cm for Sites B and $\mathrm{D}$ exceed the SCS of $\mathrm{Pb}$ for Sweden $(80 \mathrm{mg} / \mathrm{kg})$. None of the concentrations of $\mathrm{Pb}$ exceeded the SCSs for any other countries (greater than $1.4 \times 10^{2} \mathrm{mg} / \mathrm{kg}$ ). Based on our findings, some soils at industrial sites will require in-depth soil investigation or in some cases remediation. In conclusion, remediation action or proper management for $\mathrm{Cd}$, $\mathrm{Cu}$, and $\mathrm{Pb}$ contamination is necessary at some industrial sites which would be used for residential areas, based on the soil clean-up standards for some countries.

Acknowledgments This research was supported by the National Basic Research Program (called the "973" Research Program) with grant No. 2007CB407307, National Natural Science Foundation of China with grant No. C031001, and the Knowledge Innovation
Programs of the Chinese Academy of Sciences, with grant Nos. KZCX2-YW-420-5 and KZCX1-YW-06-05-02. Prof. Giesy's participation in the project was supported as an at large Chair Professorship from City University of Hong Kong and by an "Area of Excellence" Grant (AoE P-04/04).

\section{References}

Chen TB, Zheng YM, Chen H, Zheng GD (2004) Background concentrations of soil heavy metals in Beijing. Environ Sci 25:117-122 (in Chinese)

Fakoyade SO, Onianwa PC (2002) Heavy metal contamination of soil and bioaccumulation in Guinea grass (Panicumacium) around Ikeja Industrial Estate, Lagos, Nigeria. Environ Geology 43:145-150. doi:10.1007/s00254-002-0633-9

Flora SJS (2002) Lead exposure: health effects, prevention and treatment. J Environ Biol 23:25-41

Nordberg G (2003) Cadmium and human health: a perspective based on recent studies in China. J Trace Elem Exp Med 16:307-319. doi: $10.1002 /$ jtra. 10039

Nriagu JO, Pacyna JM (1988) Quantitative assessment of worldwide contamination of air, water and soils by trace metals. Nature 133:134-139. doi:10.1038/333134a0

Provoost J, Cornelis C, Swartjes F (2006) Comparison of soil cleanup standards for trace elements between countries: why do they differ? J Soils Sediments 6:173-181. doi:10.1065/jss2006.07.169

Stephens C, Hough R, Busby A, Edwards D (2004) Assessing the health risk and impact associated with living on the Thames View Estate. London School of Hygiene \& Tropical Medicine, London USEPA standard 3050B (1996) USEPA (Environment Protection Agency of United State of America) 3050B, 1996. Acid Digestion of Sediments, Sludges and Soils

Weiss P, Riss A, Gschmeidler E, Schentz H (1994) Investigation of heavy metal, PAH, PCB patterns and PCDD/F profiles of soil samples from an industrilizaded urban area (Linz, Upper Austria) with multivariate statistical methods. Chemosphere 29:2223-2336. doi:10.1016/0045-6535(94)90390-5

Yaman M, Akdeniz I (2004) Sensitivity enhancement in flame atomic absorption spectrometry for determination of copper in human thyroid tissues. Anal Sci 20:1363-1366. doi:10.2116/analsci. 20.1363 